[Agr. Biol. Chem., Vol. 35, No. 9, p. 1398 1401, 1971]

\title{
Milk-clotting Enzyme from Microorganisms
}

\section{Part IX. Reaction of Diazo-H-tetrazole on Mucor-rennin (Crystalline Milk-clotting Enzyme)}

\author{
By Juhyun YU, ${ }^{*}$ Gakuzo Tamura and Kei Arima \\ Department of Agricultural Chemistry, The University of Tokyo, Japan \\ Received March 8, 1971
}

\begin{abstract}
The milk-clotting activity of Mucor-rennin (Milk clotting enzyme of Mucor pusillus Lindt) was inhibited by reaction of diazo-1-H-tetrazole accompanied with increase of the value of the absorbance of biazo-histidine at $480 \mathrm{~nm}$. The activity did not remain when the absorbance reached $50 \% ;$ of maximum value. It is concluded from these results that one mole of histidine in 2 moles of histidine contained in the enzyme has a relation to active center.
\end{abstract}

In the previous papers, ${ }^{1,2)}$ it was reported that the crude milk-clotting enzyme was produced from Mucor pusillus Lindt cultivated on wheat bran. The enzyme was purified from the crude sample and crystallized. And, it was named Mucor-rennin., ${ }^{1,2)}$ The general properties and the amino acid composition were studied, ${ }^{1 \sim 51}$ and it was revealed that one or two moles of histidine in Mucor-rennin were related to active center by the chemical modification. ${ }^{6,7)}$ This paper describes the inhibition of the activity of the Mucor-rennin by the

* Present address: Laboratory of Microbiology, Department of Food Engineering, Yonsei University, Seoul, Korea.

1) K. Arima, J. Yu, S. Iwasaki and G. Tamura, Appl. Microbiol., 16, 1727 (1968).

2) J. Yu, S. Iwasaki, G. Tamura and K. Arima, Agr. Biol. Chem., 32, 1051 (1968).

3) J. Yu, G. Tamura and K. Arima, Biochim. Biophys. Acta, 171, 138 (1969).

4) J. Yu, G. Tamura and K. Arima, Nippon Nogeikagaku Kaishi, 43, 60 (1969).

5) J. Yu, W. Liu, G. Tamura and K. Arima, Agr. Biol. Chem., 32, 1482 (1968).

6) J. Yu, G. Tamura and K. Arima, ibid., 32, 1048 (1968).

7) J. Yu, G. Tamura and K. Arima, ibid., 35, 1194 (1971). reaction of diazo-1-H-tetrazole (DHT).

\section{EXPERIMENTAL METHOD AND MATERIALS}

Mucor-rennin crystal. The crystalline milk-clotting enzyme, Mucor-rennin, was obtained from Mucor pusillus Lindt by the purification procedures using Amberlite CG-50, DEAE Sephadex A-50 and Sephadex G-100 columns as reported in the previous paper. ${ }^{1 !}$ One gram of the crystalline enzyme was dissolved in $10 \mathrm{ml}$ of distilled water and was dialysed twice against 200 volumes of distilled water for $24 \mathrm{hr}$ to remove ammonium sulfate. The enzyme was lyophilyzed for the experiment.

Determination of milk-clotting activity. To $0.5 \mathrm{ml}$ of the enzyme solution in a tube of $25 \mathrm{ml}$ volume, $5 \mathrm{ml}$ of $1005(\mathrm{w} / \mathrm{w})$ skim milk powder solution (Snow Milk Products Co., Ltd., Japan) in $0.01 \mathrm{M} \mathrm{CaCl}_{2}$ was added. The tube was incubated at $35^{\circ} \mathrm{C}$. The milk-clotting activity was determined by the method described previously. " The amount of enzyme which clotted the substrate within $1 \mathrm{~min}$ under the above condition was defined as 400 units.

Reaction of diazo-1-H-tetrazole. The reaction of diazo-1-H-tetrazole was performed with the modified Horinishi method. ${ }^{81}$ One gram of 5-amino-1-H-tetra-

8) J. Horinishi, Y. Hachimori, K. Kurihara and K. Shibata, Biochim. Biophys. Acta, 86, 447 (1964). 
zole was dissolved in an ice bath by slow addition of $0.7 \mathrm{~g}$ of sodium nitrite in $10 \mathrm{ml}$ of water. The $\mathrm{pH}$ value of this acidic solution of DHT was adjusted to pH 5.0 with $\mathrm{KOH}$ before mixing with the enzyme solution. The final volume of the DHT solution was filled up to $100 \mathrm{ml}$. This solution was used as initial DHT solution. DHT solution was mixed with $2 \mathrm{ml}$ of $0.5 \mathrm{M} \mathrm{KH} \mathrm{PO}_{4}-\mathrm{NaOH}$ buffer ( $\mathrm{pH} 6.0$ ) and enzyme solution $(1 \mathrm{ml})$. The solution was reacted at room temperature. After completion of the reaction, the amount of the diazotized histidine residue (biazo-histidine) in the enzyme was determined by the measurement of value of the absorbance at $480 \mathrm{~nm}$ with Hitachi spectrophotometer.

\section{RESULTS}

Effect of DHT concentration on the milk-clotting activity

Diazo-1-H-tetrazole solution was diluted to double the original volume. One $\mathrm{ml}$ of the diluted DHT solution was mixed with $0.015 \%$ Mucor-rennin $(10 \mathrm{ml})$ and $\mathrm{KH}_{2} \mathrm{PO}_{4}-\mathrm{NaOH}$ buffer $(\mathrm{pH} 6.0,2 \mathrm{ml})$. The mixture was reacted

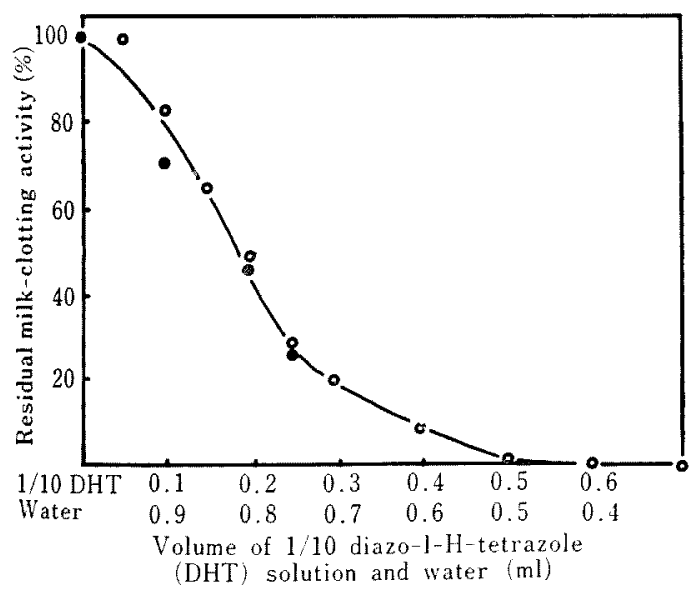

FIG. 1. Effect of Concentration of Diazo-1-H-tetrazole on Inhibition of Milk-clotting Activity of Mucor-rennin.

Residual milk-clotting activity was determined after Mucor-rennin-diazo-1-Hi-tetrazole solution was allowed to stand at $35^{\circ} \mathrm{C}$ for $90 \mathrm{~min}(\mathrm{O})$ and 180 $\min$ at room temperature for 90 to $180 \mathrm{~min}$. Milkclotting activity was inhibited by the addition of DHT. The residual milk-clotting activity was gradually decreased as the concentration of added DHT increased. The activity was completely inactivated with the addition of $0.6 \mathrm{ml}$ of the diluted DHT solution (Fig. 1).

\section{Effect of DHT on absorbancy at $480 \mathrm{~nm}$ milk-} clotting activity of mucor-rennin

The initial DHT solution or the DHT solution which was diluted to double the original volume was added to the enzyme solution. The residual activity was inactivated gradually with the reaction-time accompanied with the increase of the absorbance at $480 \mathrm{~nm}$. The absorbance value curves were observed as two step type as shown in Fig. 2. When the absorbance at $480 \mathrm{~nm}$ reached around 0.19 , the

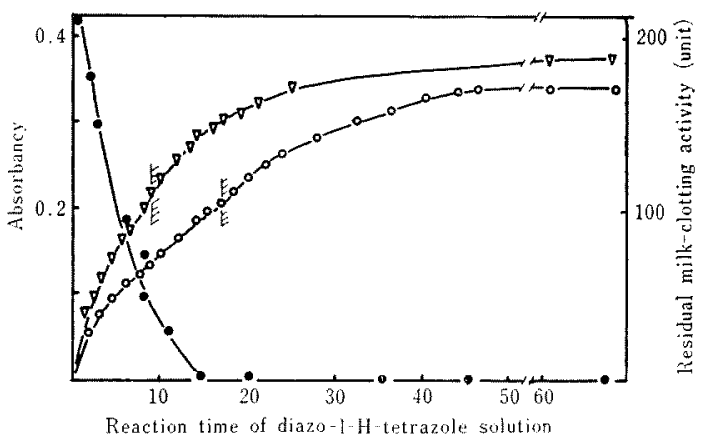

FIG. 2. Relation between Absorption at $480 \mathrm{~nm}$ and Milk-clotting Activity through Reaction Time of Diazo-1-H-tetrazole.

Milk-clotting activity (1/2 DHT): at $480 \mathrm{~nm}:(1 / 2 \mathrm{DHT}) \mathrm{O}, \mathrm{DHT} \nabla$.

$0.086 \%$ Mucor-rennin was reacted with DHT at $\mathrm{pH} 6.0$ and room temperature $\left(21^{\circ} \mathrm{C}\right.$ ).

curve manifested a shoulder, which indicated a two step reaction. The reaction of DHT coupling was faster under the initial DHT concentration than that under the diluted DHT solution. The absorbance at $480 \mathrm{~nm}$ was 0.19 after the diluted DHT solution was mixed with the enzyme and the residual milk-clotting 
activity was completely lost. The maximum value at $480 \mathrm{~nm}$ was 0.38 , which was assumed to be 10096 . Relation between residual milkclotting activity and rate of the absorbance at $480 \mathrm{~nm}$ is illustrated in Fig. 3. The milkclotting activity became zero unit when the rate of the absorbance reached $50 \%$.

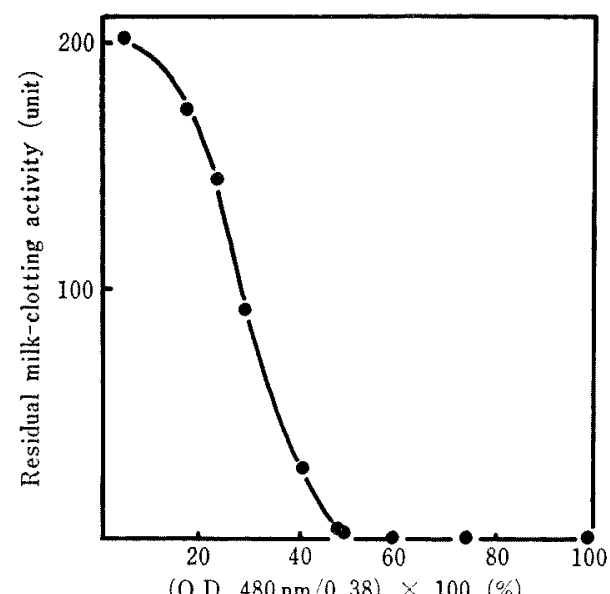

FIG. 3. Relation between Residual Milk-clotting Activity and Absorbancy at O.D. $480 \mathrm{~nm}$ by Diazo1-H-tetrazole-reaction at $\mathrm{pH} 6.0$.

\section{DISCUSSION}

DHT was found to possess the following characteristics superior to those of common diazonium compounds for the quantitative determination of histidine in amino acid mixtures or proteins. ${ }^{81}$ Histidine biazo-1-H-tetrazole has a strong absorption band at $480 \mathrm{~nm}$, while tyrosine biazo-1-H-tetrazole has a weaker band at a considerably longer wave length of $550 \mathrm{~nm}$, so that the effect of overlapping of the biazotyrosine band on the absorption at $480 \mathrm{~nm}$ is much smaller than those observed with common diazonium compounds. Moreover, the bis coupling to histidine residues in proteins is completed before the bis coupling to tyrosine residues. The only exception was the coupling to the strong bond residue in chymotrypsinogen. One can, therefore, observe the bis coupling to histidine residues separately from that to tyrosine residues. All of the histidine residues in lysozyme, insulin, albumin, and trypsin were found to react uniformly with DHT to give biazo-histidine residues. On the other hand, the reaction curves obtained for trypsinogen, chymotrypsinogen and $\alpha$-chymotrypsin showed two steps of absorbancy change and revealed the presence of bound histidine residues.

Mucor pusillus is a thermophilic mold ${ }^{9 !}$ which produces a crude milk-clotting enzyme under aerated condition. $^{10,11}$ The crude enzyme was purified and crystallized." The general physicochemical properties, reaction of the Mucor rennin on casein in agar gel of the Mucorrennin were studied. ${ }^{1-5)}$ The crystalline milkclotting enzyme has an acid protease activity. The optimum $\mathrm{pH}$ for the digestion of $\kappa$-casein is 4.5 , while that for hemoglobin digestion is 4.0. The physical properties of the crystalline enzyme are as follows; partial specific volume is 0.74 ; sedimentation coefficient is $2.39 \times 10^{-13}$ (cm.g. $\mathrm{sec}^{-1} \cdot$ dyne $^{-1}$ ); diffusion coefficient $(7.9$ $\left.\times 10^{-7} \mathrm{~cm}^{2} \mathrm{sec}^{-1}\right)$; frictional coefficient $\left(f / f_{0}\right)$, 1.33. Molecular weight was given as 29,000 by Svedverg's method and 30,600 by Yphantis's method. The number of amino acid residues contained in 1 mole of protein of the crystalline enzyme is 277 281 ((1/2 Cys $)_{2}$, Met $_{3}$, $\mathrm{Asp}_{44}$. Thr ${ }_{21}, \mathrm{Ser}_{22}, \mathrm{Glu}_{20}, \mathrm{Pro}_{14}, \mathrm{Gly}_{34}, \mathrm{Ala}_{16 \sim 17}$, $\mathrm{Val}_{24}, \mathrm{Ile}_{12}, \mathrm{Leu}_{15}, \mathrm{Tyr}_{13}, \mathrm{Phe}_{9}, \mathrm{His}_{1 \sim 2}, \mathrm{Lys}_{11 \sim 12}$, $\left.\mathrm{Arg}_{4}, \operatorname{Trp}_{2 \sim 3}\right)$. It is found that the content of histidine in the enzyme is 2 mole by Goodwin's corrected method. In the studies of active site of Mucor-rennin by chemical modification, ${ }^{6,71}$ the activity was inhibited by the reaction of iodine and photooxidation of methylene blue.

9) D. G. Cooney and R. E. Merson, "Thermophylic fungi," W. H. Freman and Co., San Francisco, 1964, pp. $17 \sim 27$.

10) K. Arima, S. Iwasaki and G. Tamura, Agr. Biol. Chem., 31, 540 (1967).

11 ) G. A. Somukuti and F. J. Babel, J. Bacteriol, 95, 1415 (1968). 
The results suggested that tyrosine, tryptophane and histidine residues in the enzyme has a relation to active site. Among these amino acids, the histidine residue was morer apidly reacted than other amino acids. A parallel relation was observed between the decreased amount of histidine residue and inactivation of the enzyme. From the results, it is concluded that one or two mole of the histidine residue contained in one mole of Mucor-rennin has a relation to active center of this enzyme. Under alkaline condition, the enzyme was inactivated spontaneously. Therefore, the experiment of DHT was not performed. At $\mathrm{pH} \mathrm{6.0,} \mathrm{the} \mathrm{activity}$ was inhibited and the absorbance at $480 \mathrm{~nm}$ increased. The absorbance curve showed two step-reaction at 0.19 of O.D. $480 \mathrm{~nm}$. The activity was completely lost at this point. At the first step below 0.19 , active histidine residue is diazonated earlier than other residue, and the absorbance value of more than 0.19 is due to coupling of inactive histidine residue. On the other hand, when the absorbance reach $50 \%$ of the maximum value, the activity was completely lost. It is evident from these results that histidine is involved in the active site of Mucor-rennin as illustrated in previous papers, ${ }^{6,7)}$ and that one of the two molecules of histidine contained in the enzyme has a relation to active center. 